\title{
EVALUASI PENERAPAN ISO 9001:2015 \\ PADA PT PULAU SAMBU GROUP (PSG) SUNGAI GUNTUNG KABUPATAN INDRA GIRI HILIR RIAU
}

\author{
Denny Handayani \\ Department of Management FEB UMM \\ E-mail: dennyhandayani98@gmail.com
}

\begin{abstract}
PT Pulau Sambu Guntung was a company engaged in the plantation sector, industry and trade, companies that process raw materials into a cream of coconut and palm oil producing strain.In the supply of raw materials, the company acquired by purchase from the supplier, and the company has a coconut plantation which is only taken $10 \%$ of the plantation area.Because it will be exported to Europe then came the problem because in Europe the standard is set too high, the ISO shall not be granted and must make improvements.This study aimed to analyze the application and the requirements of the quality management system ISO 9001: 2015.The analysis tool used is descriptive analysis.The results showed that the clause was appropriate and meet the target, but there is a clause that is appropriate but not running optimally.Therefore still needs to be improved continuously in order to run optimally.
\end{abstract}

Keywords: ISO 9001: 2015, quality management system

\section{PENDAHULUAN}

Saat ini perkembangan yang berlangsung sangat cepat yang tidak dapat dihindari baik dari sektor pemerintah maupun swasta. Perkembangan tersebut menuntut semua pihak untuk mempersiapkan diri dalam menyusun langkahlangkah yang produktif maupun antisiptuf sebaik mungkin untuk bisa bertahan dalam menghadapi konsidi persaingan. Hal ini menyebabkan perusahaan harus mempunyai daya saing yang tinggi agar tidak tenggelam diantara kompetitornya.

Kualitas telah menjadi harapan dan impian bagi semua pihak baik konsumen maupun produsen. Beberapa yang menentukan kualitas karena konsumen yang melihat barang tersebut layak untuk dibeli dan dapat bertahan lama. Merek yang bagus juga berpengaruh terhadap kualitas juga.

Kualitas sangat penting mengingat dengan kualitas tersebut perusahaan dapat dikenal karena memiliki barang dan jasa yang baik. Kualitas berpengaruh terhadap penurunan harga karena produk berkualitas akan lebih efektif dan efisien dalam produksi dan dapat memenuhi harapan konsumen.

Standar kualitas sangat penting bagi perusahaan karena untuk menilai perusahaan tersebut bagus atau tidak dilihat dari standar yang ditentukan oleh perusahaan itu 
sendiri. Kualitas menunjukkan bahwa perusahaan dapat bersaing dengan kompetitor.

Meningkatnya persaingan membuat perusahaan menyadari pentingnya kualitas. ISO 9001 telah menjadi standar/persyaratan dalam perdagangan dunia dan sebagai salah satu wujud jaminan terhadap kualitas yang dijual. Standar tersebut sudah menjadi hal yang mutlak bagi perusahaan dalam meningkatkan kepuasan pelanggan.

Kualitas merupakan kunci dari keunggulan bersaing di dalam pasar. Kualitas dapat meningkatkan reputasi perusahaan maka perusahaan yang telah menghasilkan produk dan jasa yang berkualitas dianggap perusahaan yang memiliki kualitas yang tinggi.

Kualitas membuat suatu produk atau jasa yang ditawarkan perusahaan lebih dikenal. Dengan meningkatnya persaingan kualitas produk dan jasa yang dihasilkan maka perusahaan dituntut untuk bertanggung jawab terhadap desain, proses, atau pendistribusian produk tersebut untuk memenuhi kebutuhan dan harapan pelanggan.

Kualitas produk tentunya didasarkan pada merek dan harga. Sedangkan harga menjadi faktor dalam menentukan pembelian suatu produk. Tetapi karakteristik tersebut hanya menggambarkan output atau hasil dari suatu proses tanpa memperhatikan produk tersebut selama produksinya sehingga tidak heran jika menimbulkan salah persepsi terhadap mutu tersebut.

PT. Pulau Sambu Guntung (PT. PGS) merupakan perusahaan yang bergerak dalam bidang perkebunan, industri, perdagangan, serta pengolahan bahan baku kelapa menjadi cream coconut dan memproduksi minyak mentah saring. Dalam penyedia bahan baku perusahaan memperoleh dengan cara membeli dari supplier dan perusahaan juga memiliki perkebunan kelapa yang luasnya $\pm 1.030 \mathrm{Ha}$. Akan tetapi kebutuhan bahan baku tidak mencukupi bila hanya perkebunan milik sendiri karena hanya sekitar $10 \%$ saja, sementara bahan baku terpaksa di peroleh dari supplier.

Dengan berjalannya waktu maka muncul permasalahan yaitu PT. PGS tidak memenuhi persyaratan untuk ISO ke Eropa karena standar yang ditetapkan Eropa kepada PT. PGS terlalu tinggi sehingga ISO Eropa tidak dapat dikabulakan dan terus melakukan perbaikan sehingga kedepannya dapat memenuhi persyaratan ISO Eropa.

Berdasarkan uraian di atas maka penelitian ini akan mengambil judul "Evaluasi Penerapan ISO 9001:2015 pada PT. PGS". Tujuan dari penelitian ini adalah untuk mengetahui dan menganalisis penerapan sistem manajemen mutu ISO 9001:2015 pada PT. PGS dan unuk mengetahui dan menganalisis persyaratan ISO 9001:2015.

\section{TINJAUAN PUSTAKA}

Kualitas telah menjadi harapan dan impian bagi semua orang baik konsumen maupun produsen. Konsumen mencari kualitas terbaik dalam membeli produk dan jasa yang dibutuhkan dan memiliki kualitas yang bagus dari produk yang laris dipasaran. Menurut Kotler (2012) kualitas adalah keseluruhan ciri serta sifat dari suatu produk atau 
pelayanan yang berpengaruh pada kemampuannya untuk memuaskan kebutuhan yang dinyatakan atau tersirat.

Menurut Vincent Gasperz (2003:4) kata mutu atau kualitas memiliki banyak definisi yaitu definisi konvensional dari mutu atau kualitas adalah menggambarkan karakteristik langsung berbeda dari suatu seperti penampilan (performance), keandalan (reability), mudah dalam penggunaan (easy to use), estetika (esthetics).

Produk memiliki arti penting bagi perusahaan karena tanpa adanya produk perusahaan tidak akan dapat melakukan apapun dari usahanya. Pembeli akan membeli produk kalau merasa cocok, karena itu produk harus disesuaikan dengan keinginan ataupun kebutuhan pembeli agar pemasaran produk berhasil. Menurut Kotler (2005) kualitas produk adalah keseluruhan ciri serta dari suatu produk atau pelayanan pada kemampuan untuk memuaskan kebutuhan yang dinyatakan/ tersirat.

Produk tidak dapat dipisahkan oleh kualitas, jika kualitas perusahaan tersebut bagus maka kualitas pada produk yang ditawarkan pun memiliki kualitas yang baik. Menurut Kotler dan Amstrong (2001) adapun atribut yaitu merek yang terdiri dari pengemasan (packing), kualitas produk (product quality). Untuk meningkatkan kualitas produk perusahaan dapat menerapkan total quality manajemen (TQM). Selain mengurangi kerusakan produk, tujuan pokok kualitas total adalah untuk meningkatkan nilai pelanggan.

Karakteristik kualitas dari suatu produk sangat penting, karena produk dapat memberikan kepuasan dari nilai kepada pelanggan dalam banyak cara. Karakteristik beberapa produk secara kuantitatif mudah ditentukan sepertti berat, panjang, dan waktu penggunaan, tetapi karakteristik yang lain seperti yang lain seperti daya produk adalah bersifat kualitatif.

Davin Gavin mengembangkan dimensi kualitas ke dalam delapan dimensi yang dapat digunakan sebagai dasar perencanaan strategi terutama bagi perusahaan manufaktur. Kedelapan dimensi adalah sebagai berikut :performance (kinerja), features, reliability, conformance (kesesuaian), durability (daya tahan), serviceability, estetika, perceived.

Djatmiko dan Junaedi (2011) ISO adalah suatu pedoman dan persyaratan yang digunakan suatu organisasi untuk menghasilkan produk yang bermutu dan sesuai dengan keinginan pelanggan.

Menurut Sobana (2012:10) adalah dalam manajemen mutu (quality management) dirangkai dengan manajemen terpadu yang kemudian lebih dikenal dengan manajemen mutu terpadu (total quality management TQM). Tujuan dari sistem manajemen mutu adalah kepuasan pelanggan. kepuasan ditujukkan melalui terpenuhi standar ISO yang disepakati.

Proses pengolahan atau manajemen yang dilakukan terus menerus berdasarkan baku secara berorientasi mutu dikenal sebagai sisem manajeme mutu. Sebuah perusahaan atau organisasi yang telah diaudit dan disetifikasi sebagai perusahaan yang memenuhi 
persyaratan-persyaratan dalam ISO 9001 berhak mencantumkan label.

Menurut Sobana (2012:10) adalah dalam manajemen mutu (quality management) dirangkai dengan manajemen terpadu yang kemudian lebih dikenal dengan manajemen mutu terpadu (total quality management TQM). ISO 9000 adalah menetapkan persyaratan-persyaratan dan rekomendasi untuk desain..

ISO 9001 yang dikenal dengan sistem manajemen mutu yang pertama kali dipublikasikan tahun 1987. Dalam versi 1994 standar ini direvisi. Yang kemudian standar ini direvisi kembai pada 15 Desember 2000 dan revisi terakhir pada tahun 2008.

Braun (2005) mengatakan di dalam ISO 9001 perusahaan lebih ditekankan untuk fokus terhadap prosedur dan standarisasi agar dapat memberikan kepuasan kepada konsumen.

Salah satu perubahan utama pada ISO 9001:2015 adalah adanya pendekatan yang sistematis terhadap resiko, alih-alih menganggapnya sebagai sebuah standar manajemen tersndiri di luar sistem manajemen mutu. Perubahan dan perbedaan ISO 9001:2015 klausul bertambah yang semula 8 menjadi 10 , istilah baru untuk dokumen pada ISO 9001:2015, tidak ada prosedur wajib, manual mutu tidak wajib, manajemen representative tidak harus ada, tidak ada pengecualian klausul, mengganti istilah.

\section{METODE PENELITIAN}

Peneliti mengambil lokasi di PT. PGS Kabupaten Indra Giri Hilir yang berkedudukan di Kecamatan
Kateman Sei Guntung (INHIL) Kepulauan RIAU. Jenis penelitian menggunakan aplikasi model. Indriantoro dan Supomo (2009) adalah jenis penelitian yang menekankan pada pemecahan masalh-masalah prakis yang diarahkan untuk menjawab pertanyaan spesifik dalam rangka penentuan kebijakan kinerja tertentu

Supardi populasi adalah suatu kesatuan individu atau obyek pada wilayah dan waktu serta dengan kualitas tertentu yang diamati/teliti, maka tim audit ada 2 orang dari PT. PGS. Sampel menurut Supardi adalah bagian dari populasi yang dijadikan subyek penelitian sebagai wakil dari anggota populasi, maka pada penelitian mengambil 1 orang dari tim audit yaitu bapak Mardiono dari populasi

Variabel dan definisi operasional dalam penelitian ini terdiri dari 8 klausul anatara lain: (1) Konteks organisasi, adalah mengidentifikasi apa saja pengaruh baik internal maupun eksternal baik hukum, teknologi, budaya, sosial, dan ekonomi serta visi misi. (2) Kepemimpinan, proses untuk mempengaruhi atau member contoh oleh pemimpin kepada pengikutnya atau karyawan. (3) Perencanaan, membuat strategi agar tercapainya sebuah tujuan, membuat strategi untuk mencapai tujuan dan mengembangkan rencana aktivitas kerja organisasi. (4) Pendukung, berisi tentang sumber daya, infrastruktur, manusia, lingkungan, pemantauan dan pengukuran sumber, kompetensi, kesadaran, komunikasi, dan informasi diumentasi. (5) Operasi, berfokus pada produksi mulai dari bahan mentah hinggan 
bhan siap pakai dimana yang kemudian di lakukan pengembangan, pengawetan dan pengendalian. (6) Evaluasi kerja adalah pengkuran akan efektifitas strategi yang digunakan dalam upaya mencapai tujaun perusahaan. (7) Perbaikan adalah tindakan yang dilakukan untuk melakukan perbaikan atas kondisi ketidaksesuaian yang telah terjadi

Data primer menurut Sugiyono (2008:137) adalah sumber data yang langsung memberikan kepada pengumpulan data. Dan datanya berupa jawaban dari hasil wawancara dari pihak audit mengenai klausul 4 konteks organisasi, klausul 5 kepemimpinan, klausul 6 perencanaan, klausul 7 pendukung, klausul 8 operasi, klausul 9 evaluasi kerja dan klausul 10 perbaikan. Data sekunder menurut Sugiyono (2008:137) adalah sumber data yang diperoleh dengan cara membaca, mempelajari dan memahami melalui media dan buku buku dan dokumen perusaahaan. Data berupa dokumendokumen dari klausul ISO 9001:2015 klausul 4 hinggan 10

Teknik pengumpulan data menggunakan wawancara. Wawancara kepada bapak Mardiono yaitu tim audit dari PT. PGS. Dokumentasi berupa dokumendokumen terkait dengan klausulklasuul ISO 9001:2015. Teknik analisis data dalam penelitian ini terdiri dari 3 tahapan, yaitu reduksi data, penyajian data, dan conduction drawing.

Dalam reduksi data, data yang diperoleh dari lapangan seperti kondisi umum penerapan manajemen mutu. Tujuannya memberikan gambaran yang lebih jelas dan mempermudah untuk melakukan pengumpulan data selanjutnya (Sugiono 2014). Adapun langkahlangkahnya antara lain antaralain mendeskripsikan gambaran umum perusahaan dan penerapan ISO 9001:2015 pada PT. PGS

Penyajian data dari memilih halhal pokok. Tujuannya dalam memudahkan untuk memahami hasil penelitian (Sugiono 2014). adapun langkah-langkahnya adalah, pertama melakukan evaluasi penerapan ISO 9001:2015 pada PT. PGS. Kedua melakukan analisis pengukuran klausul yang sudah dilakukan PT. PGS. Ketiga mencocokkan persyaratan ISO 9001:2015 dengan ISO 9001:2015 yang ada di perusahaan. Keempat evaluasi ISO yang mampu memenuhi persyaratan dalam penerapan ISO 9001:2015. Kelima mengidentifikasi kendala dalam penerapan ISO 9001:2015.

Kriteria penilaian evaluasi adalah skor 0 : jika organisasi atauperusahaan memahami apa yang diperlukan atau percaya itu di perlukan, skor 1 : jika organisasi atau perusahaan tidak melakukan aktivitas tersebut, skor 2 : jika organisasi atau perusahaan memahami aktivitas ini adalah hal baik untuk laakukan tetapi tidak melakukannya, skor 3 : jika organisasi atau perusahaan melakukan aktivitas terkadang saja, skor 4 : jika organisasi melakukan aktivitas tetapi belum sempurna, skor 5 : jika organisasi atau perusahaan melakukan aktivitas dengan baik.

Range dari penjumlahan bobot sebagai berikut, $75 \%-100 \%$ untuk perusahaan atau suatu organisasi siap untuk melakukan sertifikasi, 50\%$74 \%$ untuk perusahaan atau suatu organisasi harus memperbaiki untuk 
persiapan ISO 9001:2015, 1\%-49\% sistem manajemen kualitas suatu perusahaan sangat butuh perbaikaan karena berbeda jauh dari sistem manajemen kualitas ISO 9001:2015

\section{HASIL PENELITIAN DAN PEMBAHASAN}

Penerapan ISO 9001:2015 pada PT. PGS akan di analisis berdasarkan beberapa klausul seperti yang akan dijelaskan pada paragraf selanjutnya. Pertama klausul 4 yaitu tentang Konteks Organisasi yang terdiri dari beberapa sub-klausul. Klausul 4.1. memahami organisasi dan konteksnya. Salah satu aspek adalah budaya dari PT. PGS 5S yaitu Seiri (Ringkas), Seiketsu (Rawat), Shitsuke(Rajin), Seiso (Rapi), Seiso (Resik). Visi PT PSG adalah kami bertekad untuk menjadikan produkproduk PT. PGS sebagai standar mutu dunia. Misi PT PSG adalah kami berekad untuk meningkatkan kesejahteraan ekonomi dan hidup yang bermutu bagi seluruh pihak terkait.

Klausul 4.2. memahami kebutuhan dan harapan pihak yang berkepentingan, yaitu kebutuhan seperti hp, air minum (ases) dan jalan raya dengan harapan semua dapat terpenuhi secara maksimal terutama untuk jalan raya karena jalan masih menggunaka tempurung kelapa yang ketika ujan akan becek dan membuat tidak nyaman. Klausul 4.3 menentukan lingkup sistem manajemen mutu, dengan adanya jadwal audit yang sudah di tetapkan oleh PT, yaitu selama 2 hari dengan kategori makanan, minuman dan kesehatan dan memiliki tim audit sendiri.
Klausul 4.4. tentang sistem manajemen mutu dan prosesprosesnya. Pada PT. PGS ada proses utama dimana memilih kelapa yang tua karena memiliki air yang lebih banyak kemudian diproses menggunakan mesin yang menghasilkan santan yang kemudian di distribusikan ke Jakarta. Proses pendukung yaitu dengan memelihara peralatan, setelah dipakai langsung di cuci sehingga keesokannya bisa langsung dipakai.

Klausul 5 tentang kepemimpinan yang terdiri dari beberapa subklausul. Klausul 5.1. tentang kepemimpinan dan komitmen. Pada PT. PGS pemimpin memantau karyawannya dalam bekerja dan penerapan dalam sistem manajemen mutunya. Manajer sudah memiliki tugas dan tanggung jawabnya. Selain itu ada struktur organisasi yang sebagai bukti bahwa PT. PGS memiliki tugas dan tanggung jawab.

Klausul 5.2. tentang fokus pelanggan. fokus pelanggan PT. PGS menggunakan survey kepada pelanggan dan bisa juga langsung bertanya kepada pelanggan bagaimana produk yang dihasilkan oleh PT tersebut. Klausul 5.2.1. tentang mengembangkan kebijakan mutu. Adapun kebijakan mutu PT. PGS adalah produksi dan pelayanan pengiriman pelayanan bermutu untuk kepuasan pelanggan, total komitmen dalam implementsi ISO, peninjauan dan keseuaian keefektifan kebijakan mutu, dan giat membangun pola pikir mutu. Terbukti di setiap departemen ada kebijakan mutu. Klausul 5.2.2. tentang berkomunikasi kebijakan mutu, melakukan visi misi perusahaan. PT. PGS bertekad untuk 
membuat produk tersebut terkenal hingga ke seluruh dunia dan bertekad juga membuat yang bekerja pada PT tersebut dapat terjamin kehidupannya.

Klausul 5.3. tentang peran organisasi, tanggung jawab dan kewenangannya. Tanggung jawab dan wewenang pada PT PSG adalah menyerahkan tanggung jawab dan wewenang pada asisten, mengatur dan mengetahui cuti dan surat ijin karyawan, member peringatan dan disiplin kerja pada karyawan, mengetahui dan menandatangani laporan, member teguran dan sanksi kepada karyawan jika mengabaikan aspek keamanan.

Klausul 6. adalah tentang perencanaan yang terdiri dari beberapa sub-klausul. Klausul 6.1. tentang tindakan untuk mengatasi risiko dan peluang. Untuk mengatasi risiko dan peluang PT. PGS menggunakan analisis tulang ikan. Klausul 6.2. tentang sasaran mutu dan perencanaan untuk mencapainya. Tujuan mutu PT. PGS yaitu meningkatkan penyelesaian pesananan kerja dengan pemberian target penyelesaian, meningkatkan presentase kehadiran karyawan dengan mengontrol khadiran, meminimalkan biaya maintance department denga mengontrol biaya, mengontrol presensi lembur, meminimalkan nesin-mesin perkakas sesuai dengan jadwal, meminimalkan kerusakan peralatan kerja, mempertahankan jam training departemen.

Klausul 7. adalah tentang pendukung yang terdiri dari beberapa sub-klausul. Klausul 7.1.1. tentang sumber daya manusia. PT. PGS menyediakan dan mengelola sumber daya manusia. Karyawan yang ditunjuk memiliki kompetensi yang memadai atas tugas dan tanggung jawabnya dan meningkatkan kemampuan dan keahlian melalui pelatihan, workshop dan seminar.

Klausul 7.1.3. tentang infrastruktur. PT. PGS memiliki mess yang diperuntukkan karyawan, bus untuk antar jemput karyawan, fasilitas wifi didalam kantor dan juga ada jangkaua jaringan provider. Klausul 7.1.4 tentang lingkungan untuk pengoperasian proses. PT. PSG membuat jadwal dan pemeliharan kebersihan, mencuci mesin setelah dipakai untuk produksi dan memastikan bahwa limbah tidak berbahaya dan mencemari lingkungan.

Klausul 7.1.5. tentang pemantauan dan pengukuran sumber. Pada PT. PSG alat ukur di kalibrasi selama 6 bulan sekali. Alat ukurnya berupa tabung angin, timbangan digital, di atur terangnya cahaya, mngatur kebisingan mesin untuk tingkat kebisingan manusis sebesar 30 desibel dan maksimal 60 desibel. Klausul 7.1.6. tentang pengetahuan organisasi. PT. PSG mengadakan wokshop dan pelatihan selama seminggu dan diambil 1 karyawan dari setiap deprtemen.

Klausul 7.2 tentang kompetensi, untuk mengembangkan kompetensi PT. PSG selalu bersusaha meningkatkan kemampuan baik hard skill maupun soft skill melalui pelatihan- pelatihan sehingga diharapkan tercipta tenaga kerja yang memiliki kompeten tinggi. Klausul 7.3. tentang kesadaran. Untuk menumbuhkan kesadaran PT PSG melakukan pelatihan yang dilakukan satu minggu sekali dan di ambil dari 
setiap departemen 1 orang jadi tidak mengganggi pekerjaan. Klausul 7.4.. tetang komunikasi, PT. PSG memiliki program yaitu apapun yang diminta konsumen maka harus langsung ditangani terutama untuk departemen jasa.

Klausul 7.5. tentang informasi doumentasi. Pada PT. PSG yang bertanggung jawab adalah dari pihak SD, yang memiliki informasi dokumentasi secara lengkap. Klausul 7.5.2. tentang membuat dan memperbaharui, PT. PSG membuat tanggal dan berapa jumlah yang akan diproduksi setiap harinya sehingga tidak ada barang yang cacat atau barang yang rusak.

Klausul 8. adalah tentang operasi yang terdiri dari beberapa sub-klausul. Klausul 8.1. tentang perencanaan dan pengendalian operasional. Produk yang diproduksi PT. PGS harus bermanfaat bagi lingkungn sekitar pabrik dan dengan bahan yang berkualitas sehingga sampai ketangan konsumen, selain itu dalam proses produksi selalu melakukan pengecheckan agar produksi etap bersih dan higienis. Klausul 8.2. tentang persyaratan untuk produk dan layanan. Pada PT. PSG setiap tahapan proses dilakukan verifikasi dan validasi oleh setiap departemen sehingga jika terjdi ketidaksesuaian dan di telusuri apa penyebabnya.

Klausul 8.2.1. tentang komunikasi pelanggan menggunakan iklan dan promosi. Zaman sekarang yang serba praktis maka komunikasi juga dengan cara sms pengaduan dan kuesioner. Klausul 8.2.2. tentang penentuan persyaratan yang berkaitan dengan produk dan jasa. Spesifikasi produk sudah di cantumkan oleh PT PSG yang juga sudah di tentukan dan juga sudah mengetahui apa yang diinginkan oleh pelanggan. Klausul 8.2.4. tentang perubahan persyaratan. Pada PT. PSG untuk produk dan layanan, perubahan dilakukan selama 6 bulan sekali dan dilakukan secara bertahap.

Klausul 8.3.2 tentang desain dan pengembangan perencanaan. PT. PSG melakukan perencanaan untuk desain dan pengembangannya yang berkaitan dengan produk dan jasa dan berkaitan dengan ruang lingkup produksi yang memiliki tahap tahapan dalam desain dan pengembangan terhadapa tanggung jawab dan wewenang. Klausul 8.3.3. tentang desain dan pengembangan input. PT. PSG dilakukan secara periodik yaitu 6 bulan sekali. Terbukti adanya audit yang dilakukan selama 6 bulan sekali.

Klausul 8.3.4. tentang desain dan pengembangan control. PT. PSG melakukan pengontrolan yang berguna supaya desain dan pengembangan tersebut dapat berjalan sesuai dengan apa yang di rencanakan dan sesuai dengan apa yang diharapkan. Klausul 8.3.5 tentang desain dan pengembangan output. Pada PT. PSG setelah dilakukan secara periodik kemudian dilakukan peninjauan untuk mengetahui berbagai dampak yang ditimbulkan maka dilakukan tindakan perbaikan yang lebih cepat dan lebih murah.

Klausul 8.3.6 tentang desain dan pengembangan perubahan. Pada PT. PSG pengembangan dilakukan tetapi dengan mengidentifikasi perubahan tentang bukti-bukti bahwa perubahan tersebut dilakukan juga mempertimbangkan berbagai 
dampak dari perubahan dan perencanaan.

Klausul

8.4.

tentang pengendalian proses eksternal yang disediakan, produk dan layanan. Pada PT. PGS data pelanggan yang berupa dari nama pelanggan dan apa saja pengaduannya memiliki masa berlaku yaiu selama 2 tahun, setelah itu data tersebut di musnahkan atau bisa juga di bakar karna tidak penting lagi bagi perusahaan.

Klausul 8.4.2 tentang jenis dan jangkauan pengendalian. PT. PSG melakukan pengendalian dan pengawasann dalam kegiatan proses produksi, dari memilih bahan baku yang baik dan bagus hingga proses produksi selesai dan harus dilakukan secara teliti dan hati-hati.

Klausul 8.4.3 tentang informasi untuk penyedia eksternal. PT. PSG harus mengkomunikasikan apa saja yang menjadi persyaratan bagi pemasok dan harus bertanggung jawab jika terjadi sesuatu dan menjamin bahwa kelayakan terhadap persyaratan tersebut. Dengan memilih pemasok yang harus bertanggung jawab dan dapat memenuhi kebutuhan oleh PT. PSG.

Klausul 8.5.1 tentang pengendalian produksi dan penyediaan jasa, yaitu upaya PT. PGS untuk memberikan produk yang berkualitas dan bermutu tinggi dan bertanggung jawab sesuai yang direncanakan. Terbukti produk sudah melewati banyak uji coba untuk kepuasan pelanggan. Klausul 8.5.2 tentang identifikasi dan mampu telusur, proses produksi yang dilakukan oleh PT. PSG yaitu mulai dari bahan mentah hingga barang jadi yang kemudian sampai lah ke tangan konsumen.
Klausul 8.5.3 tentang properti milik pelanggan dan penyedia eksternal. Properti milik pelanggan berupa nama dan umur mereka yang kemudaian apa saja masalah yang di hadapi dan bagaimana cara mengatasi masalah tersebut. Adanya kotak saran dan sms pengaduan merupakan bukti bahwa PT memiliki data pelanggan.

Klausul tentang $\quad 8.5 .4$ pengawetan, PT. PGS melakukan pengawetan tetapi sesuai dengan prosedur yang sudah di tetapkan dan merupakan rahasia dari perusahaan itu sendiri. Klausul 8.5.5 tentang kegiatan post-delivery, yaitu kegiatan yang dilakukan dengan mengantar pesanan-pesanan santan langdung ke tangan konsumen dan mengirim ke retail-retail yang sudah bekerja sama terhadap perusahaan.

Klausul 8.5.6 tentang pengendalian perubahan, dengan cara menilai dan merekam keabsahan hasil pengukuran seelumnya. Bila tidak memenuhi persyaratan maka dilakukan tindakan yang sesuai. klausul 8.5.7 tentang pengendalian output tidak sesuai, pengendalian output yang tidak sesuai PT. PSG menghapus dan menghancurkan dan masa berlakunya 2 tahun. Data rahasia berupa data pelanggan, data penggajian yang bersifat rahasia.

Klausul 9 adalah tentang evaluasi kerja yang terdiri dari beberapa sub-klausul. Klausul 9.1.2 tentang kepuaasan pelanggan.PT. PSG melakukan kepuasan pelanggan dengan cara survey untuk mengetahui apakah produk yang di tawarkan sesuai dengan permintaan pelanggan dan standar harapan pelanggan terhadap produk tersebut. Klausul 9.1.3 tentang analisis dan 
evaluasi. Pada PT. PSG dianalisis bagaimana cara meningkatkan penjualan produk dan supaya dapat bertahan dari saingan produk yang berada di luar sana kemudian dievaluasi apa saja yang menjadi hambatan dan kendala dalam menerepakan atau menawarkan produk kepada pelanggan.

Klausul 9.2 tentang audit internal. PT. PSG melakukan audit selama 6 bulan sekali dan dilakukan oleh audit eksternal. Klausul 9.3.2 tentang masukkan tinjauan manajemen. PT. PSG melakukan tinjauan manajemen selama 6 bulan sekali yang biasanya dibahas adalah hasil audit, umpan balik dari pelanggan, kinerja proses dan kesesuain dan saran-saran untuk perbaikan apabila terdapat ketidaksesuaian.

Klausul 9.3.3 tentang keluaran tinjuan manajemen. Pada PT. PSG hasil rapat dicatat oleh notulen. Catatan tersebut berisi mengenai keputusan dan tindakan yang harus dilakukan untuk memperbaiki keefektifan perbaikan sesuai dengan persyaratan dan meninjau sumber daya yang dibutuhkan.

Klausul 10 adalah tentang perbaikan. Klausul 10.3 tentang perbaikan berkelanjutan. PT. PGS mewujudkan dengan menyusun prosedur perbaikan dan memastikan perbaikan dilaksanakan efektif serta menyusun prosedur pencegahan dan memastikan pencegahan dilaksanakan efektif. Kegiatan tersebut dilakukan berdasarkan kebijakan mutu, sasaran mutu, hasil audit, analisis dan tindakan perbaikan dan pencegahan serta tinajuan mnajemn guna memperbaiki keefektifan secara terus menerus.

Hasil dari tindakan pencegahan dilakukan keefektifannya, hal ini diperlukan untuk memastikan bahwa masalah yang ada benar-benar tidak akan terjadi. Masalah yang dimaksud adalah masalah ketidaksesuaian.

Tabel 2. Analisis Presentase Ketidaksesuaian dengan Persyaratan ISO 9001:2015 Presentase Penilaian Setiap Klausul

\begin{tabular}{cccc}
\hline Persyaratan & Skor & Skor maksimal & Presentase penilaian \\
\hline Klausul 4 konteks organisasi & 20 & 20 & $100 \%$ \\
Klausul 5 kepemimpinan & 27 & 30 & $90 \%$ \\
Klausul 6 perencanaan & 15 & 15 & $100 \%$ \\
Klausul 7 pendukung & 54 & 65 & $83 \%$ \\
Klausul 8 operasi & 98 & 140 & $70 \%$ \\
Klausul 9 evaluasi kerja & 30 & 35 & $85 \%$ \\
Klausul 10 perbaikan & 10 & 10 & $100 \%$ \\
\hline
\end{tabular}

Dari Tabel 2. diatas dapat diketahui bahwa Klausul 4, konteks organisasi, dalam penilaiannya memiliki skor maksimal dimana setiap klausul diberi nilai sesuai dengan dokumen perusahaan dan memiliki skor 20 dengan presentase $100 \%$ bahwa prosedur kerja dan persyaratan dijalankan dengan baik.
Klausul 5 kepemimpinan memiliki jumah Klausul 6 yang memiliki skor 27 dengan skor maksimal 30 dan memiliki nilai presentase $90 \%$ beberapa prosedur kerja belum dijalankan namun persyaratan lain dijalankan dengan baik.

Klausul 6, perencanaan, memiliki jumlah Klausul 3 dengan 
skor 15 dan skor maksimal 15 sesuai dengan dokumen yang ada diperusahaan dan dengan presentase $100 \%$ bahwa prosedur kerja dan persyaratan dijalankan dengan baik. Klausul 7 pendukung memiliki 13 klausul dengan skor 54 yang memiliki skor maksimal 65 dengan presentase $83 \%$ bahwa beberapa prosedur kerja belum dijalankan namun persyaratan lain dijalankan dengan baik.

Klausul 8, operasi, memiliki 23 klausul yang memiliki skor 98 dengan skor maksimal 140 dan memiliki presentase $70 \%$ bahwa banyak prosedur kerja yang belum dijalnkan namun sebagian persyaratan yang tidak mewajibkan prosedur kerja yang diterapkan dimana sesuai dengan dokumen pada perusahaan.

Klausul 9, evaluasi kerja, memiliki 7 klausul dengan skor 30 dengan skor maksimal 35 dengan jumlah presentase $85 \%$ bahwa beberapa prosedur belum dijalankan namun persyaratan lain dijalankan dengan baik. Klausul 10 perbaikan memiliki 2 klausul dengan skor 10 dan skor maksimal 10 dengan presentase $100 \%$ dimana prosedur kerja dan persyaratan dijalankan dengan baik.

Dari perhitungan presentase yang telah dilakukan bahwa range penilaian berada pada kisaran $70 \%$ $100 \%$ karena presentase dari yang terkecil hingga yang terbesar adalah $70 \%$ dan $100 \%$. Hal ini berarti terdapat beberapa prosedur kerja yang belum dijalankan namun persyaratan lain dijalankan dengan baik. Banyaknya ketidaksesuain menuntut perusahaan untuk menjalankan komitmen dalam pemenuhan kepuasan pelanggan. sistem manajemen mutu ini harus segera diperbaiki untuk menunjang kelancaran proses produksi dan perbaikan berkesinambungan dalam segala hal.

Penerapan pada PT. PGS sudah berjalan lama dan hampir semua persyaratan sudah dilakukan dengan baik dan telah sesuai dan sudah dilakukan oleh perusahaan. Dan penerapannya sudah sesuai yang berada pada kisaran 75\%-100\% perushaan atau suatu organisasi siap untuk melengkapi ISO 9001:2015 dan berada pada klausul 4 konteks organisasi, Klausul 5 kepemianampinan, Klausul 6 perencanaan, Klausul 7 pendukung, Klausul 9 evalusi dan Klausul 10 perbaikan. Dan selebihnya berada pada kisaran 50\%-70\% yaitu perusahaan suatu organisasi harus memperbaiki untuk persiapan ISO 9001:2015 adalah Klausul 8 operasi.

\section{SIMPULAN}

Berdasarkan hasil analisis, dapat diambil simpulan bahwa penerapan ISO 9001:2015 pada PT. PGS sudah berjalan sejak lama, dimana seluruh klausul yang dipersyaratkan dalam standar yang telah sesuai dan dilaksanakan oleh perusahaan. Dan penerapannya pun sudah berjalan sesuai yang sudah diharapkan oleh perusahaan. Penerapan ISO 9001:2015 yang telah sesuai pada PT. PGS, kriteria yang berada pada 75\%-100\% perusahaan atau suatu organisasi siap untuk melengkapi ISO 9001:2015 dan melakukan sertifikasi adalah klausul 4 Konteks Organisasi, Klausul 5 Kepemimpinan, Klausul 6 Perencanaan, Klausul 7 Pendukung, 
Klausul 9 Evaluasi Kerja, Klausul 10 Perbaikan. Kriteria yang berada pada $50 \%-70 \%$ perusahaan atau suatu organisasi harus memperbaiki untuk persiapan ISO 9001:2015 adalah klasul 8 Operasi.

\section{DAFTAR PUSTAKA}

Aditya Twin Prakasa dkk. "Analisis penerapan sistem manajemen mutu ISO 9001:2008 menggunakan GAP ANALYSIS TOOLS (studi kasus PT Sahabat Rubbers Industries , Malang”. Jurnal rekayasa dan manajemen sistem industri Vol. 3 No. 1

Amirudin. 2014. "Evaluasi penerapan ISO 9001:2008 dilingkungan UIN Syarif Hidayatullah Jakarta”. Jurnal ekonomi, Vol. 13. No. 1.

Bernard E. \& Sugianto Y 2011. "Implementasi sistem manajemen mutu ISO 9001:2008 pada industry kontraktor (studi kasus PT MAK)". Esensi volume 14. No. 3

Davin O. T. 2014. "Penerapan sistem manajemen mutu ISO 9001:2008 di PT Brantas Teknik Unggul", Jurnal ilmiah mahasiswa universitas Surabaya, Vol. 3. No. 1

Garvin \& Davis. 2005. Manajemen mutu terpadu. Terjemahan $\mathrm{M}$.
N. Nasution. Erlangga

Gaspersz, Vincent. 2003. Total quality manajemen. Gramedia pustaka utama

Gaspersz, Vincent. 2006. Total quality manajemen untuk praktisi bisnis dan industri, Jakarta. Gramedia pustaka utama

http://konsultaniso.web.id/iso90012015

Rully, I. \& Poppy, Y. 2014 Metodologi penelitian kuantitatif, kualitatif dan campuran untuk manajemen, pembangunan dan pendidikan. Cetakan ke satu September 2014. PT Retika Aditama

Subana, H. E. 2012. Tips memahami sistem manajemen mutu ISO 9001. Alfabeta.

Sugiyono. 2008. Metode penelitian bisnis. Bandung. Alfabeta.

Sukanto R. \& Indroyono G. 1993. Manajemen Produksi edisi keempat BPFE. Yogyakarta.

Syukur, Agus. 2010. 5R,ISO 9001:2008 dan Poka Yoke. Yogyakarta: Kata Buku www.kompas.com.

Tjiptono, Fandy. 2005. Pemasaran Jasa, Edisi pertama. Malang: Bayu Media Publishing.

Zulian Yamit. 2004. Manajemen kualitas produk dan jasa. Cetakan ketiga, Ekonisia Yogyakarta. 